\title{
Environmental Triggers of Type 1 Diabetes
}

\author{
Mikael Knip and Olli Simell \\ Children's Hospital (MK), University of Helsinki and Helsinki University Central Hospital, Fl-00014 Helsinki, \\ Finland; Folkhälsan Research Center (MK), FI-00290 Helsinki, Finland; Department of Pediatrics (MK), Tampere \\ University Hospital, FI-33520 Tampere, Finland; and Department of Pediatrics (OS), University of Turku and \\ Turku University Hospital, FI-20014 Turku, Finland \\ Correspondence: mikael.knip@helsinki.fi
}

Type 1 diabetes (T1D) is perceived as a progressive immune-mediated disease, the clinical diagnosis of which is preceded by an asymptomatic preclinical period of highly variable duration. It has long been postulated that the disease process leading to overt T1D is triggered by an infectious agent, the strongest candidate being a diabetogenic enterovirus. The initiation and progression of the disorder likely requires, in addition to genetic T1D susceptibility, a trigger, an exogenous antigen capable of driving the development of this disease. This may be a dietary antigen similar to gluten in celiac disease. Recent data further suggests that the initiation of autoimmunity is preceded by inflammation reflected by a proinflammatory metabolic serum profile. The cause of the inflammation remains open, but given that the intestinal microbiome appears to differ between individuals who progress to clinical T1D and nonprogressors, one may speculate that changes in the gut microflora might contribute to the inflammatory process.

\begin{abstract}
Type 1 diabetes (T1D) is perceived as a chronic immune-mediated disease with a subclinical prodromal period characterized by selective loss of insulin-producing $\beta$ cells in the pancreatic islets of genetically susceptible subjects. The most important genes contributing to disease susceptibility are located in the HLA-DQ locus on the short arm of chromosome 6 (Pociot et al. 2010). It has been estimated that the HLA genes explain approximately one-half of the genetic susceptibility for this disease, whereas the other half is caused by more than 50 non-HLA genetic polymorphisms. Nevertheless, only a relatively small proportion of genetically susceptible in-
\end{abstract}

dividuals progress to clinical disease. This implies that additional factors are needed to trigger and drive the disease process in genetically predisposed subjects.

Environmental factors have long been implicated in the pathogenesis of T1D both as triggers and potentiators of $\beta$-cell destruction (Åkerblom et al. 2002; Knip et al. 2005; Peng and Hagopian 2006). Several lines of evidence support a critical role for exogenous factors in the pathogenesis of T1D. Studies on monozygotic twins suggest that only $13 \%-33 \%$ are pair-wise concordant for T1D (Barnett et al. 1981; Kaprio et al. 1992), implying that there

Editors: Jeffrey A. Bluestone, Mark A. Atkinson, and Peter Arvan

Additional Perspectives on Type 1 Diabetes available at www.perspectivesinmedicine.org

Copyright (C) 2012 Cold Spring Harbor Laboratory Press; all rights reserved; doi: 10.1101/cshperspect.a007690

Cite this article as Cold Spring Harb Perspect Med 2012;2:a007690 
is either acquired postconceptional genetic discordance, or differential exposure to the putative environmental factor(s). The geographic variation in the incidence of T1D in children is conspicuous even among Caucasians, with the lowest annual rate in Europe reported from Macedonia, amounting to 3.2/100,000 in children under the age of 15 years (The European ACE Study Group 2000) whereas the highest rate was observed in Finland, reaching 63/100,000 in 2006 (Knip 2011). This almost 20-fold difference in incidence can hardly be explained by genetic factors alone. Furthermore, the substantial increase in the incidence of T1D among children over recent decades cannot be the consequence only of enhanced genetic disease susceptibility in the population, but largely must be caused by changes in lifestyle and environment.

Migrant studies indicate that the incidence of T1D has increased in population groups who have moved from a low incidence region to a high incidence area, also emphasizing the influence of environmental conditions. Accumulating evidence suggests that the proportion of subjects with high-risk HLA genotypes has decreased over the last decades among patients with newly diagnosed T1D, whereas the proportion of those with low-risk or even protective HLA genotypes has increased (Hermann et al. 2003; Gillespie et al. 2004). These data are compatible with an increased environmental pressure, resulting in progression to clinical diabetes with less genetic predisposition. Here, we set out to consider environmental triggers and determinants of T1D with an emphasis on recent observations.

\section{THE DIABETIC DISEASE PROCESS}

The disease process leading to the clinical manifestation of T1D in childhood initiates early, in most cases even before the age of 3 years (Parikka et al. 2012). The progression rate is, however, highly individualized. If seroconversion to positivity for one or more diabetes-associated autoantibody is accepted as a biomarker of the initiation of the disease process, the duration of the disease process ranges from a few months to more than 20 years (Knip et al. 2010a). Our experience is that if an individual presents with T1D in childhood, the average duration of the asymptomatic preclinical period is about $2.5-3$ years.

Genetic disease susceptibility is conferred by defined HLA and non-HLA genes (Fig. 1). The HLA class II genotype has a strong impact on the rate of seroconversion to autoantibody positivity. In the Finnish Diabetes Prediction and Prevention (DIPP) study, the seroconversion rate to positivity for two or more autoantibodies was almost three times higher among those with the high risk genotype (i.e., HLA DQA ${ }^{*} 05$ DQB1*02/DQB1*0302) than in those with moderate risk genotypes (Kukko et al. 2004). HLA class I alleles may also influence progression from the appearance of $\beta$-cell autoimmunity to overt T1D. For example, we have observed that among HLA DR3/DR4 heterozygous subjects with preclinical T1D, those with the HLA B39 allele progress faster and more frequently to overt diabetes than those lacking B39 (Lipponen et al. 2010). The same effect could not be seen among children with other HLA class II genotypes.

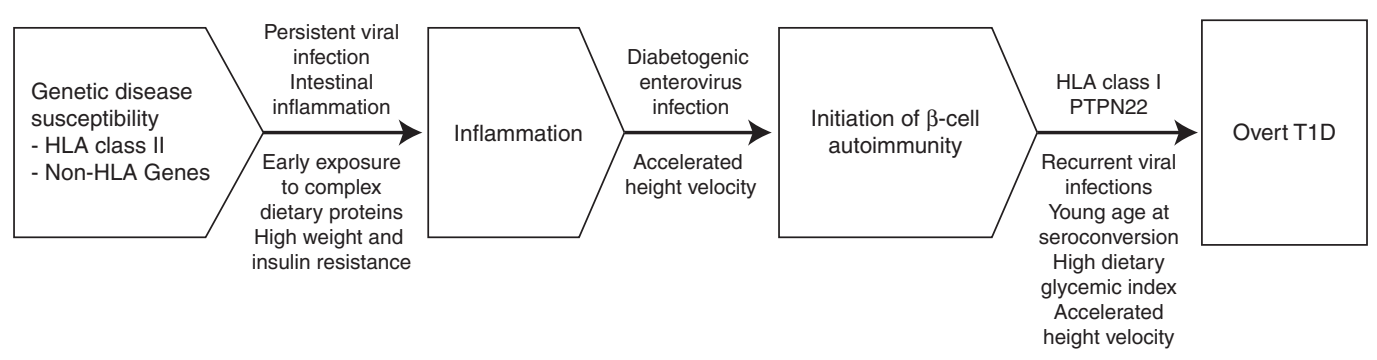

Figure 1. Progression from genetic disease susceptibility to overt T1D. The appearance of signs of $\beta$-cell autoimmunity is preceded by a proinflammatory state, the etiology of which is so far open. 
Diabetes-associated autoantibodies are markers of humoral $\beta$-cell autoimmunity. There are at least five autoantibody reactivities including classical islet cell antibodies (ICA), insulin autoantibodies (IAA), antibodies to the $65 \mathrm{kD}$ isoform of glutamic acid decarboxylase (GADA), the protein tyrosine phosphatase related islet antigen 2 molecule (IA-2A) and zinc transporter 8 (ZnT8A); each of which has been confirmed to be predictive of T1D (Siljander et al. 2009; Wenzlau et al. 2007). Persistent positivity for two or more autoantibodies is highly predictive of progression to clinical diabetes, whereas single autoantibody positivity may reflect "harmless" $\beta$-cell autoimmunity (Knip and Siljander 2008). The consensus has been that autoreactive $\mathrm{T}$ cells are responsible for the $\beta$-cell destruction resulting in overt T1D, whereas the autoantibodies are innocent bystanders useful as predictive markers of future disease. The observation in patients with recent-onset T1D that treatment with the antiCD20 monoclonal antibody targeting B cells results in a retarded loss of endogenous insulin secretion of the same magnitude as that seen with therapies affecting T-cell function (Pescovitz et al. 2009) challenges that concept, in part.

Recent metabolomics studies have indicated that seroconversion to autoantibody positivity is preceded by inflammation (Orešič et al. 2008; Pflueger et al. 2011). The factors inducing such a proinflammatory state are poorly defined, but one may speculate that either a chronic viral infection in the pancreatic islets, dietary factors, and intestinal inflammation due to changes in the gut microbiome alone or in combination might contribute to this process. The role of the gut in the pathogenesis of T1D has been emphasized by Vaarala et al. (2008), pointing out the complex interplay between the intestinal microbiome, gut permeability, and mucosal immunity, which may contribute to the formation of the disease.

$\beta$-cell autoimmunity may be induced early in life (Ziegler et al. 1999; Kimpimäki et al. 2001b). Data from the DIPP study have shown that the first autoantibodies may appear already before the age of 3 months, that about $9 \%$ of these children recruited from the general pop- ulation based on increased HLA DQB1-conferred risk develop persistent positivity for at least one autoantibody by the age of 5 years, and that close to $4 \%$ seroconvert to persistent positivity for multiple $(>2)$ antibodies by that age (Kukko et al. 2005).

\section{VIRUSES}

Viral infections have been implicated in the etiology of T1D for more than 100 years. More recently, a variety of studies have suggested that certain viruses are associated with autoimmune diabetes in experimental animals. Seroepidemiological human studies further indicate that enteroviruses, in particular, play a role in progression toT1D (Hyöty and Taylor 2002; Yeng et al. 2011). Viruses may act by at least two possible mechanisms, either via a direct cytolytic effect, or by triggering an autoimmune process leading gradually to $\beta$-cell destruction. Beyond this, the role of molecular mimicry in diabetesassociated autoimmune responses has been indicated by the observations of structural homology between viral structures and $\beta$-cell antigens. Persistent or slow virus infections may also be important in the induction of autoimmunity.

\section{Enteroviruses}

The enterovirus (EV) genus is part of the large picornavirus family. They are small nonenveloped RNA viruses which are the most common viruses causing human diseases. There are more than 100 different EV serotypes, which usually cause mild or asymptomatic infections. However, occasionally the virus spreads to the myocardium or central nervous system leading to myocarditis, encephalitis, or paralysis. Infections are common already in very young infants, and newborn babies are at risk of getting systemic multiorgan infections, which can be fatal (Tauriainen et al. 2011).

We have shown in the DIPP study a close temporal association between the appearance of the first diabetes-associated autoantibodies and EV infections (Lönnrot et al. 2000; Oikarinen et al. 2011). In addition, we have observed an 
obvious temporal variation in the appearance of the first autoantibodies fitting very well into the annual pattern of EV infections with the highest rate in the fall and winter (Kimpimäki et al. 2001a). These observations imply that a diabetogenic EV infection is the most likely trigger of $\beta$-cell autoimmunity in a substantial proportion of cases seroconverting to autoantibody positivity. Subsequently, we have analyzed in a systematic study neutralizing antibodies to $41 \mathrm{EVs}$ from the first autoantibody positive samples in 183 DIPP children testing persistently positive for two autoantibodies and in more than 360 autoantibody-negative control children matched with the cases for gender, HLA genotype, and date and location of birth. Neutralizing antibodies are serotype specific and relatively persistent, and accordingly our analyses reveal which infections the child has experienced before their seroconversion. The initial analysis revealed that the cases had had more infections caused by Coxsackie virus B1 (CBV1) and fewer infections caused by B3 and B6 (Laitinen et al., unpubl.). In the next step, we analyzed the neutralizing antibodies to the six
CBV serotypes in two additional samples from the same individuals (i.e., the samples obtained 12 and 6 months before seroconversion). The results showed that there was an increasing odds ratio for a CBV1 infection over time with a significantly increased risk in the sample taken at the time of seroconversion (Fig. 2). When the 119 cases that have progressed to clinical T1D were analyzed in a subanalysis, the outcome was identical. These data indicate that CBV1 is a likely trigger of $\beta$-cell autoimmunity and of the disease process leading to the manifestation of clinical T1D, whereas CBV3 and CBV6 infections may be protective.

The implicated link between EV infections and $\beta$-cell autoimmunity has been questioned, because most of the supportive data have come out of Finnish studies, and two other prospective studies (i.e., BABYDIAB in Germany and the Diabetes Autoimmunity Study in the Young (DAISY) in Denver, Colorado), failed to show any association between EV infections and $\beta$ cell autoimmunity (Fuchtenbusch et al. 2001; Graves et al. 2003). There are, however, at least three critical issues with a decisive impact on the

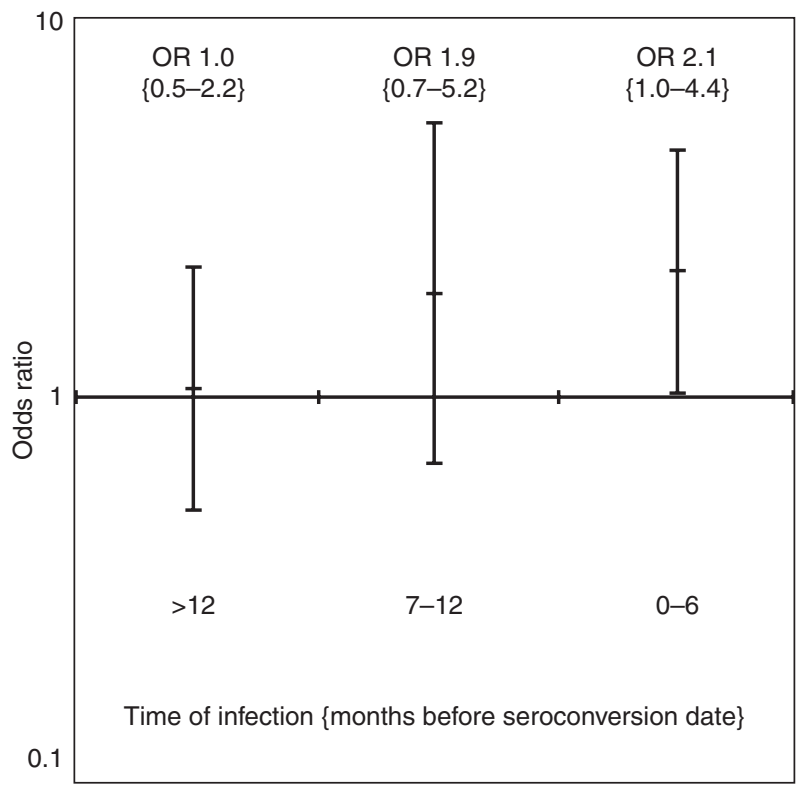

Figure 2. The odds ratio for an association between a Coxsackie virus B1 infection and seroconversion to two or more diabetes-predictive autoantibodies increases over time and is highest in the first sample with detectable $\beta$ cell autoimmunity. 
ability of any prospective study to provide meaningful observations in this context. The first one is the size of the study and the number of subjects who develop signs of $\beta$-cell autoimmunity; factors clearly related to the statistical power of the study. A second critical consideration is the study design and the sampling interval. Long sampling intervals definitely hamper the possibility to detect EV infections from collected samples. In the BABYDIAB study Coxsackie virus antibodies were measured from serum samples taken at the age of 9 months, 2 years, 5 years, and 8 years, and in DAISY the samples were obtained at the age of 9 months, 15 months, 2 years, and then annually. In contrast, the DIPP study has a more frequent sampling schedule, as samples are obtained with an interval of 3-6 months over the first 2 years of life and subsequently with an interval of 6-12 months. The third crucial point is related to the type of samples collected and the methodological arsenal used for the detection of EV infections. A more recent analysis of 140 autoantibody-positive children from the DAISY study indicated that progression to clinical T1D increased after an invasive EV infection characterized by the presence of viral DNA in blood (Stene et al. 2010). Simonen-Tikka et al. (2011) reported recently that no correlation was observed between the presence of EV in stool samples and the development diabetesassociated autoantibodies in the first year of life in the German BABYDIET study. The series included, however, only 22 autoantibody positive infants.

The novel Finnish observation that CBV1 is a diabetogenic virus needs to be confirmed in other populations. If such studies can substantiate the role of CBV1 as a risk virus, the logical approach would be to develop a vaccine against CBV1 to test whether such a vaccine would protect against $\beta$-cell autoimmunity and T1D.

\section{Other Viruses}

The list of other viruses implicated to be associated with T1D comprises the rotavirus, cytomegalovirus, mumps, rubella, Ljunganvirus, and retroviruses (Knip and Hyöty 2008). Australian researchers have reported molecular ho- mology between the VP7 protein of rotavirus and T-cell epitopes in the IA- 2 molecule and in the $65 \mathrm{kD}$ isoform of GAD (Honeyman et al. 1998, 2010). In a prospective study of infants genetically predisposed to T1D, they observed that the appearance of diabetes-associated autoantibodies was associated with significant rises in rotavirus antibodies, indicating that rotavirus infections may induce $\beta$-cell autoimmunity in genetically susceptible infants (Honeyman et al. 1999). A Finnish prospective study showed that $\sim 16 \%$ of infants and young children with HLA-conferred susceptibility to T1D 1 diabetes experienced a rotavirus infection during the 6-month window preceding the detection of the first diabetes-associated autoantibody, whereas $15 \%$ of the control subjects matched for gender, birth date, delivery hospital, and HLA genotype had signs of a rotavirus infection during the corresponding time period (Blomqvist et al. 2002). That observation failed to support the role of rotavirus infections as triggers of $\beta$-cell autoimmunity. No recent data indicate that any of the other viruses listed could function as a trigger of $\beta$-cell autoimmunity and/or the diabetic disease process.

\section{BACTERIA}

A complex and vast community of symbiotic micro-organisms inhabits the human gastrointestinal tract. The gut microbiome is modulated by dietary compounds and host factors from the early on in life. Accumulating evidence suggests that the gut microbiome may protect from the development of some metabolic diseases, T1D included, by promoting intestinal homeostasis. Wen et al. (2008) reported that specific-pathogen free NOD mice lacking the MyD88 protein, which is an adaptor for multiple innate immune receptors, do not develop autoimmune diabetes. They also showed that the effect was dependent on commensal microbes because germfree MyD88-negative NOD mice did develop robust diabetes, whereas colonization of these mice with a defined microbial consortium representing a bacterial composition normally present in the human intestine decreased the incidence of diabetes. 
M. Knip and O. Simell

A small U.S.-Finnish study including four DIPP children who eventually progressed to clinical T1D and four matched autoantibodynegative controls studied the intestinal microbiome in stool samples obtained before and at seroconversion to autoantibody positivity and close to the diagnosis of overt T1D in the cases and at corresponding ages in the control children (Giongo et al. 2011). The study showed that the progressors developed a microbiome that was less diverse and stable than that seen in the healthy controls. A more detailed analysis of the intestinal microbiome in these children revealed that nonbutyrate-producing lactateutilizing bacteria prevented optimal mucin synthesis in the progressors, whereas a consortium of lactate- and butyrate-producing bacteria induced a sufficient amount of mucin synthesis in the controls to maintain gut integrity (Brown et al. 2011).

In a recent study on the metabolic regulation during progression to autoimmune diabetes in NOD mice (Sysi-aho et al. 2011), we observed that female NOD mice, which later progressed to autoimmune diabetes, showed the same metabolic pattern as that seen in children with preclinical T1D (Oresic et al. 2008). The metabolic changes were accompanied by a decreased gut microbial diversity of the Clostridium leptum group. This observation is interesting as microbes from the Clostridium leptum group have been reported to induce regulatory $\mathrm{T}$ cells in the colonic mucosa (Atarashi et al. 2011). Accordingly, a reduced Clostridium leptum diversity may result in a decreased number and function of regulatory $\mathrm{T}$ cells promoting the autoimmune response.

\section{DIETARY FACTORS}

As previously mentioned observations from prospective birth cohort studies indicate that the first signs of $\beta$-cell autoimmunity may be induced already during the first year of life and in most cases, who present with clinical T1D in childhood, before the age of 3 years. This implies that environmental risk factors for $\beta$-cell autoimmunity and T1D must be operative in that time period, during which early nutrition provides essential exogenous exposures (Knip et al. 2010b).

\section{Breastfeeding and Complementary Feeding}

Whether breastfeeding protects against T1D or not has remained a controversial issue. There are studies showing a protective effect, no effect, or even a predisposing effect (Virtanen and Knip 2003). A series of prospective studies exploring the association between breastfeeding and the emergence of $\beta$-cell autoimmunity have reported that breastfeeding has no impact (Norris et al. 2003, Ziegler et al. 2003; Virtanen et al. 2006). There are, however, some studies indicating that short breastfeeding is a risk factor for the appearance of signs of $\beta$-cell autoimmunity (Kimpimäki et al. 2001b; Holmberg et al. 2007). There may be several reasons to these contradictory findings. Many studies have been looking at overall breastfeeding without any differentiation between exclusive and total breastfeeding. In addition, there are conspicuous differences in the breastfeeding practices between various countries.

Early introduction of cow's milk proteins (i.e., conventional infant formulas) has also been studied in relation to subsequent risk of $\beta$-cell autoimmunity and clinical disease. The introduction of infant formula reflects in general the mirror of the duration of exclusive breastfeeding. These studies have also produced contradictory outcomes (Virtanen and Knip 2003), mainly in that respect that some surveys have indicated that early introduction of cow's milk increases the risk of $\beta$-cell autoimmunity (Kimpimäki et al. 2001b; Holmberg et al. 2007) and T1D (Virtanen et al. 1991, 1993; Kostraba et al. 1993), whereas others have found no association between those two phenomena (Wadsworth et al. 1997; The EURODIAB Substudy 2 Study Group 2001). When studying at the same time the effect of the duration of breastfeeding and age at introduction of cow's milk, early exposure to cow's milk turned out to be the dominant risk determinant of T1D in a Finnish national case-control study (Virtanen et al. 1993). Again, there may be several explanations for the discrepant results. Although 
milk formula is in most cases the first foreign food an infant is exposed to all over the world, there is variation between countries and cultures in the proportion of babies first introduced to milk-based formulas. In addition, there are geographical differences in what kind of foreign foods those infants are given who are not first exposed to milk formula. For example, a substantial proportion of babies in the United States are first given cereals while this is extremely rare in Finland (Norris et al. 2003; Virtanen et al. 2006). The use of partly or extensively hydrolyzed formulas in normal infants varies considerably from country to country, and this can be expected to be an important confounder, when analyzing the association between introduction of cow's milk and the development of $\beta$-cell autoimmunity and T1D.

Two prospective studies have reported that there is an association between the introduction of cereals in infancy and the emergence of early $\beta$-cell autoimmunity. The American report suggested that both early (before the age of 4 months) and late exposure (at the age of 7 months or later) to cereals were associated with an increased risk of $\beta$-cell autoimmunity (Norris et al. 2003), whereas the German study implied that an increased risk was related to exposure to cereals before the age of 3 months (Ziegler et al. 2003). In addition the U.S. survey indicated that both gluten-containing and nongluten-containing cereals conferred an increased risk for $\beta$-cell autoimmunity. Early exposure to cereals is against generally accepted recommendations on infant nutrition in all developed countries and occurs only infrequently. For example, Finnish babies are rarely exposed to cereals before the age of 4 months. A prospective analysis of data from the DIPP study showed no relationship between early or late introduction of cereals and emergence of advanced $\beta$-cell autoimmunity (Virtanen et al. 2006).

Our analysis based on the DIPP study showed that early introduction of fruits and berries as well as of roots is associated with increased risk for advanced $\beta$-cell autoimmunity (i.e., positivity for $\geq$ two autoantibodies out of four analyzed) (Virtanen et al. 2006). A very recent study including more subjects with two or more diabetes-associated autoantibodies ( $n$ = 232) from the DIPP cohort confirmed that a high intake of fruit and berry juices was associated with an increased risk of advanced $\beta$ cell autoimmunity (Virtanen et al. 2012). That study showed also that the intake of milk-based infant formulas as well as subsequent intake of milk products increased modestly the risk of seroconversion to two or more autoantibodies.

Stene et al. (2008) reported in 2003 that the use of cod liver oil during the first year of life was related to a reduced risk of T1D. Such an association could, however, not be confirmed in a later study. Cod liver oil is composed of high concentrations of both vitamin D and omega3 polyunsaturated fatty acids. A case-cohort analysis based on the DAISY study indicated that the intake of omega- 3 fatty acids between the ages of 1 and 6 years was associated with a decreased risk of- $\beta$-cell autoimmunity (Norris et al. 2007).

Only a few pilot intervention trials modifying infant nutrition have been performed so far. In the pilot of the Trial to Reduce IDDM in the Genetically at Risk (TRIGR), 230 Finnish infants with HLA-conferred susceptibility to T1D were randomized to weaning to either an extensively hydrolyzed formula or a conventional cow's milk based formula before the age of 6-8 months. During the intervention period the families were recommended not to give any food products containing cow's milk or bovine serum albumin to their infant. The intervention resulted in a postponement of the introduction of intact cow's milk proteins by several months in the active intervention group. After followup to a median age of 10 years it turned out that the nutritional intervention in infancy resulted in a decrease in most signs of $\beta$-cell autoimmunity in the range of $50 \%-60 \%$ (Knip et al. 2010c). There was a significant reduction in the cumulative incidence of ICA, IA-2A, and positivity for at least one of the five autoantibody reactivities analyzed. This suggests that it may be possible to manipulate spontaneous $\beta$-cell autoimmunity by a relatively simple and safe intervention in the infant period. The full-scale TRIGR study is now running in 15 countries 
with 2159 randomized participants. The first end-point, positivity for two or more diabetes-associated autoantibodies and/or clinical T1D by the age of 6 years, will be reached in 2013 and the final endpoint, overt T1D by the age of 10 years, will be reached in 2017 (The TRIGR Study Group 2011).

The German BABYDIET study was initiated to explore whether delaying the introduction of gluten beyond 12 months of age will reduce the risk of $\beta$-cell autoimmunity in young children at increased risk of T1D. The recently reported outcome revealed that there was no difference in the cumulative incidence of diabetes-associated autoantibodies or clinical T1D between the lateexposure and control group (Hummel et al. 2011). A TrialNet-based pilot trial, called "The Nutritional Intervention for the Prevention of Type 1 Diabetes (NIP)" was initiated some years ago to test the feasibility of a full-scale trial addressing the hypothesis that dietary supplementation with an omega-3 fatty acid (docosahexaenoic acid [DHA]) during fetal life and in infancy will prevent $\beta$-cell autoimmunity in at-risk infants. Ninety-eight infants have been enrolled in the pilot trial and they will be observed up to the age of 4 years (Chase et al. 2009). Inflammatory mediators, including cytokines, chemokines, eicosanoids, and C-reactive protein, are measured along with fatty acids in maternal and infant blood.

\section{Bovine Insulin as a Candidate for the Role of Driving Dietary Antigen in T1D Development}

There is no direct evidence of an exogenous antigen driving the T1D disease process from initial $\beta$-cell autoimmunity to clinical disease. Accordingly, this idea is based on indirect data and parallels with celiac disease and it has to be critically assessed. In general terms, one may argue that the driving antigen must represent a relatively common exposure among the population in most developed countries, and one can also assume that there must be some variability in the exposure within and across populations.

Celiac disease provides interesting angles of approach to these issues. The causal link be- tween wheat and celiac disease was only uncovered through (unplanned) intervention: the wheat-deficient World War II diet in the Netherlands combined with its postwar improvement identified a culprit autoimmune disease causing agent: dietary gluten (Streng 1946). Without that experience, gluten would have remained most likely unidentified as the driving dietary antigen in celiac disease. It has been proposed that the HLA association in celiac disease, in which HLA DR3-DQ2 is the dominant susceptibility haplotype, can be explained by a superior ability of the DQ2 molecule to bind proline-rich gluten peptides that have survived gastrointestinal digestion and have been deamidated by tissue transglutaminase (Kim et al. 2004). This brings up two thought-provoking points. First, the most important autoantigen in celiac disease (tissue transglutaminase) seems to have a biological function in the disease process, and secondly the exogenous antigen (gluten) must be processed in a critical manner, in this case deamidated, before it is bound by the predisposing HLA molecule to be presented to T cells.

Insulin is a crucial autoantigen in T1D as it is the only $\beta$-cell specific autoantigen in postnatal life. IAA are the first or among the first autoantibodies to appear when the disease process leading to T1D is initiated in young children (Ziegler et al. 1999; Kimpimäki et al. 2001a). The frequency of IAA is also substantially higher among young children at the diagnosis of T1D than among older children and adults (Sabbah et al. 2000). As cow's milk formulas generally are the first and most common dietary source of foreign, complex proteins that an infant is exposed to in developed countries, we asked the question whether early exposure to conventional formula results in an immune response to bovine insulin present in formulas and differing from human insulin by three amino acids, two in the $\mathrm{A}$ chain and one in the $\mathrm{B}$ chain. Our study showed that the infants who were exclusively breast-fed at least up to the age of 3 months had substantially lower IgG class antibodies to bovine insulin than those who were exposed to formula before that age (Vaarala et al. 1999). All subjects were observed up to the age of 18 months. The follow-up showed 
that the IgG class insulin antibodies started to slowly decrease after the age of 3 months as a sign of the development of oral tolerance in those infants who were given formula before the age of 3 months. In contrast, in those exclusively breast-fed at least to the age of 3 months, the antibody levels increased up to the age of 12 months, and thereafter they leveled off. That antibody profile was expected, since these infants were exposed to cow's milk-based products, mostly formula, at some point during their first year of life. The study cohort included a small series of subjects $(n=11)$ who developed early signs of $\beta$-cell autoimmunity. These subjects showed continuously increasing levels of IgG antibodies to bovine insulin. This increase may partly be explained by the appearance of IAA, because there is a considerable cross-reactivity between bovine and human insulin in the insulin antibody assays. The increase in IgG antibodies to bovine insulin remained, however, significant, even after adjustment for the IAA titers. Our observation indicates that those young children who present with early signs of $\beta$-cell autoimmunity appear to lack the capacity to develop oral tolerance to bovine insulin. Accordingly, the initial immune response to bovine insulin may later be diverted into a response targeting human insulin in such individuals.

Are there any data suggesting that increased exposure to cow's milk later in childhood might confer increased risk for T1D? Data from three population-based case-control studies on cow's milk intake prior to diagnosis of T1D are conflicting. Verge et al. (1994) reported that the cow's milk intake had been higher in prediabetic children than in control children in New South Wales, Australia. In our nationwide "Childhood Diabetes in Finland" (DiMe) study, we observed that high consumption of cow's milk in childhood was associated with a more frequent appearance of diabetes-associated autoantibodies and T1D in a prospective cohort of initially unaffected siblings of children with T1D (Virtanen et al. 1998). In contrast, a Swedish retrospective survey indicated that the frequency of milk intake had been lower among children who presented with T1D than among unaffected children (Dahlquist et al. 1990).
Recent observations support the role of bovine insulin as a driving antigen in the disease process leading to overt T1D. As mentioned earlier a study based on the largest series of autoantibody-positive children analyzed so far showed that a high intake of milk products increases the risk of advanced $\beta$-cell autoimmunity in young at-risk children (Virtanen et al. 2012). A pilot intervention trial with weaning to an insulin-free formula has been performed in Finland among infants with HLA-conferred susceptibility to T1D. Follow-up data to the age of 3 years show that weaning to such a formula during the first 6 months of life reduced the cumulative incidence of diabetes-predictive autoantibodies by more than $60 \%$ when compared to infants weaned to a conventional formula (Vaarala et al., 2012).

Gluten or other cereal-derived proteins have been implicated as potential driving antigens in T1D. Two small-scale pilot intervention studies have been performed in family members testing positive for diabetes-associated autoantibodies to assess whether gluten elimination modifies the natural course of $\beta$-cell autoimmunity. In neither of the trials did the autoantibody titers change significantly during the gluten-free intervention period or during the re-exposure period (Hummel et al. 2002; Pastore et al. 2003). In addition, the BABYDIET trial reported that delayed exposure to gluten in young at-risk children had no effect on the appearance of diabetesassociated autoantibodies by the age of 3 years.

\section{Vitamin D}

Some studies have indicated that the lack of vitamin D supplementation in infancy increases the subsequent risk of T1D. A European casecontrol study (The EURODIAB Substudy 2 Study Group. 1999) from seven centers indicated that supplementation with vitamin D resulted in a reduced risk of T1D. A Finnish birth cohort study reported that both regular and irregular high-dose supplementation with vitamin D in infancy (2000 IU/day at that time vs. $400 \mathrm{IU} / \mathrm{d}$ currently) was associated with a decreased disease risk when compared to no supplementation (Hyppönen et al. 2001). A 
M. Knip and O. Simell

meta-analysis based on five studies concluded a few years ago that vitamin D supplementation in early childhood is associated with a decreased diabetes risk (Zipitis and Akobeng 2008).

There are, however, a few arguments that speak against a critical role of vitamin D deficiency in the development of $\beta$-cell autoimmunity and T1D. One consideration is that there is a general recommendation that all young children should be substituted with daily vitamin D drops in northern Europe, the area with the highest incidence of childhood T1D in the world, and this recommendation is implemented by about $80 \%$ of the parents at least up to the age of 1 year (Räsänen et al. 2006). In addition there are a few regions with a low incidence of T1D in northern Europe, e.g., Russian Karelia having an annual incidence rate of 7.8/100,000 children under the age of 15 years in the time period 1990-1999 compared to that of 42 in Finland (Kondrashova et al. 2005), whereas we found no significant differences in the circulating vitamin $\mathrm{D}$ concentrations in pregnant women and schoolchildren between Russian Karelia and Finland (Viskari et al. 2006). A recent report based on the DAISY study showed that neither vitamin D intake nor circulating $25(\mathrm{OH}) \mathrm{D}$ concentrations throughout childhood were associated with increased risk of $\beta$-cell autoimmunity or progression to T1D (Simpson et al. 2011).

\section{Other Dietary Factors}

The DAISY Study analyzed whether dietary glycemic index and glycemic load was associated with the development of signs of $\beta$-cell autoimmunity and further progression to clinical T1D. The data showed no association between dietary glycemic index or load and seroconversion to autoantibody positivity, but a higher glycemic index was associated with a more rapid progression from seroconversion to overt disease (Lamb et al. 2008)

\section{Linear Growth and Weight Gain}

Accelerated linear growth and weight gain result in an enhanced $\beta$-cell load and increasing insulin resistance (Hindmarsh et al. 1988). It has been shown experimentally that active $\beta$ cells are more prone to cytokine-induced damage than resting cells (Palmer et al. 1989). Taken together these observations imply that rapid growth induces $\beta$-cell stress. According to the accelerator hypothesis presented by Wilkin in 2001, insulin resistance is an important factor affecting the rising incidence of both T1D and type 2 diabetes, the only differences between these two forms of diabetes being the pace of progression to overt disease and the fact that those who present with T1D carry genetic susceptibility to autoimmunity.

Increased weight gain in infancy has repeatedly been reported to be a risk factor for T1D later in childhood (Knip et al. 2005). Finnish studies have shown that those children who presented subsequently with T1D were not only heavier but also taller already in infancy, although there were no significant differences in birth weight or length (Hyppönen et al. 1999, 2000). Data from the DAISY study suggest that accelerated height velocity may play a role in the progression from both genetic diabetes susceptibility to $\beta$-cell autoimmunity, and further to overt T1D in prepubertal children (Lamb et al. 2009).

\section{INTERACTIONS}

We have to keep in mind that we most likely have a complex interplay between various phenomena involved in the development of $\beta$-cell autoimmunity and T1D. There are definitely gene-gene, gene-environment, and environment-environment interactions during the disease process resulting in overt T1D. We have just started to learn about such interactions, and new insights into the disease process may be gained by exploring the interplay between the determinants contributing to the pathogenesis of T1D.

In the DIPP study we have observed an interaction between the polymorphism in the PTPN22 gene and infant feeding. The predisposing PTPN22 polymorphism was associated with a higher rate of seroconversion to positivity for diabetes-predictive autoantibodies and progression to clinical T1D only among those 
subjects who had been exposed to conventional infant formulas before the age of 6 months (Lempainen et al. 2009). No such effect was seen among the children exposed to cow's milk formula on the first occasion after the age of 6 months. In another study based on the DIPP cohort, we found an interaction between two environmental factors; namely, early EV exposure and infant feeding. An association between an early enterovirus infection (i.e., before the age of 12 months) and subsequent seroconversion to two or more diabetes predictive autoantibodies could be observed among those cases who were exposed to conventional formula before the age of 3 months, but not among the remaining children (Lempainen et al. 2012). More work has definitely to be done to identify gene-gene, gene-environment, and environment-environment interactions in the development of preclinical and clinical T1D.

\section{CONCLUDING REMARKS}

The identification of environmental trigger(s) of $\beta$-cell autoimmunity and T1D is still in its early beginnings. The identification of exogenous factors triggering and driving $\beta$-cell destruction offers a potential means for intervention aimed at the prevention of T1D. Therefore, it is important to pursue studies on the role of environmental factors in the pathogenesis of this disease. Environmental modification is likely to offer the most powerful strategy for effective prevention of T1D, because such an approach can target the whole population or at least that proportion of the population carrying increased genetic disease susceptibility; therefore, preventing both sporadic and familial T1D, if successful. This consideration is crucial, because the sporadic cases comprise $83 \%-98 \%$ of all children with newly diagnosed diabetes according to a comparative European survey (The EURODIAB ACE Study Group and The EURODIAB ACE Substudy 2 Study Group. 1998). The results of the second pilot study of the TRIGR project suggest that it is possible to manipulate the spontaneous appearance of $\beta$-cell autoimmunity by dietary modification early in life in high risk individuals, thereby representing the first indication that environmental modification may affect the natural history of preclinical T1D (Knip et al. 2010c).

More research is definitely needed to delineate the contribution of environmental factors and their interactions with predisposing and/ or protective genes to the development of $\beta$-cell autoimmunity and overt T1D. The interplay between different environmental factors has to be mapped and the mechanistic pathways have to be defined. New approaches, such as metabolomics, epigenomics, and metagenomics should be applied creatively and without any prejudice to facilitate progress in this area.

\section{ACKNOWLEDGMENTS}

This research was supported by Academy of Finland, Juvenile Diabetes Research Foundation International, Special Research Funds for University Hospitals in Finland, Finnish Diabetes Research Foundation, the Novo Nordisk Foundation, Sigrid Jusélius Foundation, Liv och Hälsa Fund, Päivikki, and Sakari Sohlberg Foundation, Signe and Ane Gyllenberg Foundation, European Foundation for the Study of Diabetes, and European Commission (DIAPREPP and TORNADO Consortiums).

\section{REFERENCES}

Åkerblom HK, Vaarala O, Hyöty H, Ilonen J, Knip M. 2002. Environmental factors in the etiology of type 1 diabetes. Am J Med Genet 115: 18-29.

Atarashi K, Tanoue T, Shima T, Imaoka A, Kuwahara T, Momose Y, Cheng G, Yamasaki S, Saito T, Ohba Y, et al. 2011. Induction of colonic regulatory $\mathrm{T}$ cells by indigenous Clostridium species. Science 331: 337-341.

Barnett AH, Eff C, Leslie RDG, Pyke DA. 1981. Diabetes in identical twins. A study of 200 pairs. Diabetologia 20: 87-93.

Blomquist M, Juhela S, Erkkilä S, Korhonen S, Simell T, Kupila A, Vaarala O, Simell O, Knip M, Ilonen J. 2002. Rotavirus infections and development of diabetes-associated autoantibodies during the first 2 years of life. Clin Exp Immunol 128: 511-515.

Brown CT, Davis-Richardson AG, Giongo A, Gano KA, Crabb DB, Mukherjee N, Casella G, Drew JC, Ilonen J, Knip M, et al. 2011. Gut microbiome metagenomics analysis suggests a functional model for the development of autoimmunity for type 1 diabetes. PLoS ONE 6: e25792. 
Chase HP, Lescheck R, Rafkin-Mervis L, Krause-Steinrauf H, Chritton S, Asare S, Adams S, Skyler JS, Clare-Salzier M, Type 1 Diabetes Trialnet NIP Study Group. 2009. Nutritional intervention to prevent (NIP) type 1 diabetes: A pilot trial. Infant Child Adolesc Nutr 1: 99-107.

Dahlquist GG, Blom L, Persson LÅ, Sandström AI, Wall SG. 1990. Dietary factors and the risk of developing insulin dependent diabetes in childhood. $\mathrm{Br}$ Med J 300: 13021306.

Fuchtenbusch M, Irnstetter A, Jager G, Ziegler AG. 2001. No evidence for an association of coxsackie virus infections during pregnancy and early childhood with development of islet autoantibodies in offspring of mothers or fathers with type 1 diabetes. J Autoimmun 17: 333-340.

Gillespie KM, Bain SC, Barnett AH, Bingley PJ, Christie MR, Gill GV, Gale EA. 2004. The rising incidence of childhood type 1 diabetes and reduced contribution of high-risk HLA haplotypes. Lancet 364: 1699-1700.

Giongo A, Mukherjee N, Gano KA, Crabb DB, Casella G, Drew JC, Ilonen J, Knip M, Hyöty H, Veijola R, et al. 2011. Toward defining the autoimmune microbiome for type 1 diabetes. ISME J 5: 82-91.

Graves PM, Rotbart HA, Nix WA, Pallansch MA, Erlich HA, Norris JM, Hoffman M, Eisenbarth GS, Rewers M. 2003. Prospective study of enteroviral infections and development of $\beta$-cell autoimmunity. Diabetes autoimmunity study in the young (DAISY). Diabetes Res Clin Pract 59: $51-61$.

Hermann R, Knip M, Veijola R, Simell O, Laine AP, Åkerblom HK, Groop PH, Forsblom C, Petterson-Fernholm $\mathrm{K}$, Ilonen J, et al. 2003. Temporal changes in the frequencies of HLA genotypes in patients with type 1 diabetesindication of an increased environmental pressure? Diabetologia 46: 420-425.

Hindmarsh PC, Matthews DR, Di Silvio L, Kurz AB, Brook CG. 1988. Relation between height velocity and fasting insulin concentrations. Arch Dis Child 63: 665-666.

Holmberg H, Wahlberg J, Vaarala O, Ludvigsson J, the ABIS studygroup. 2007. Short duration of breast-feeding as a risk factor for $\beta$-cell autoantibodies in 5-year-old children from the general population. Br J Nutr 97: 111-116.

Honeyman MC, Stone NL, Harrison LC. 1998. T-cell epitopes in type 1 diabetes autoantigen tyrosine phosphatase IA-2: Potential for mimicry with rotavirus and other environmental agents. Mol Med 4: 231-239.

Honeyman MC, Coulson BS, Stone NL, Gellert SA, Goldwater PN, Steele CE, Couper JJ, Tait BD, Colman PG, Harrison LC. 1999. Association between rotavirus infection and pancreatic islet autoimmunity in children at risk of developing type 1 diabetes. Diabetes 49: 1319-1324.

Honeyman MC, Stone NL, Falk BA, Nepom G, Harrison LC. 2010. Evidence for molecular mimicry between human $T$ cell epitopes in rotavirus and pancreatic islet autoantigens. J Immunol 184: 2204-2210.

Hummel M, Bonifacio E, Naserke HE, Ziegler AG. 2002. Elimination of dietary gluten does not reduce titers of type 1 diabetes-associated autoantibodies in high-risk subjects. Diabetes Care 25: 1111-1116.

Hummel S, Pflüger M, Hummel M, Bonifacio E, Ziegler AG. 2011. Primary dietary intervention study to reduce the risk of islet autoimmunity in children at increased risk for type 1 diabetes: The BABYDIET study. Diabetes Care 34: 1301-1305.

Hyöty H, Taylor KW. 2002. The role of viruses in human diabetes. Diabetologia 45: 1353-1361.

Hyppönen E, Kenward MG, Virtanen SM, Piitulainen A, Virta-Autio P, Knip M, Åkerblom HK, the Childhood Diabetes in Finland Study Group. 1999. Infant feeding, early weight gain and risk of type 1 diabetes. Diabetes Care 22: 1961-1965.

Hyppönen E, Virtanen SM, Kenward MG, Knip M, Åkerblom HK, the Childhood Diabetes in Finland Study Group. 2000. Obesity, increased linear growth and risk of type 1 diabetes mellitus in children. Diabetes Care 23: $1755-1760$.

Hyppönen E, Läärä E, Järvelin MR, Virtanen SM. 2001. Intake of vitamin D and risk of type 1 diabetes: A birth cohort study. Lancet 358: 1500-1504.

Kaprio J, Tuomilehto J, Koskenvuo M, Romanov K, Reunanen A, Eriksson J, Stengård J, Kesäniemi YA. 1992. Concordance for Type 1 (insulin-dependent) and Type 2 (non-insulin-dependent) diabetes mellitus in a population-based cohort of twins in Finland. Diabetologia 35: 1060-1067.

Kim CY, Quarsten H, Bergseng E, Khosla C, Sollid LM. 2004. Structural basis for HLA-DQ2-mediated presentation of gluten epitopes in celiac disease. Proc Natl Acad Sci 101: 4175-4179.

Kimpimäki T, Kupila A, Hämäläinen A-M, Kukko M, Kulmala P, Savola K, Simell T, Muona P, Ilonen J, Simell O, et al. 2001a. The first signs of $B$-cell autoimmunity appear in infancy in genetically susceptible children from the general population: The Finnish Type 1 Diabetes Prediction and Prevention Study. J Clin Endocrinol Metab 86: $4782-4788$.

Kimpimäki T, Erkkola M, Korhonen S, Kupila A, Virtanen SM, Ilonen J, Simell O, Knip M. 2001b. Short exclusive breast-feeding predisposes young children with increased genetic risk of type 1 diabetes to progressive $\beta$-cell autoimmunity. Diabetologia 44: 63-69.

Knip M. 2011. Pathogenesis of type 1 diabetes: Implications for incidence trends. Horm Res 76: 57-64.

Knip M, Hyöty H. 2008. Environmental determinants: The role of viruses and standard of hygiene. In Epidemiology of Pediatric and Adolescent Diabetes (ed. Dabelea D, Klingensmith GJ), pp. 63-64. Informa Healthcare, New York.

Knip M, Siljander H. 2008. Autoimmune mechanisms in type 1 diabetes. Autoimmun Rev 7: 550-557.

Knip M, Veijola R, Virtanen SM, Hyöty H, Vaarala O, Åkerblom HK. 2005. Environmental triggers and determinants of $\beta$-cell autoimmunity and type 1 diabetes. Diabetes 54: S125-S136.

Knip M, Korhonen S, Kulmala P, Veijola R, Reunanen A, Raitakari OT, Viikari J, Åkerblom HK. 2010a. Prediction of type 1 diabetes in the general population. Diabetes Care 33: 1206-1212.

Knip M, Virtanen SM, Åkerblom HK. 2010b. Infant feeding and risk of type 1 diabetes. Am J Clin Nutr 91: 1506S$1513 S$.

Knip M, Virtanen SM, Seppä K, Ilonen J, Savilahti E, Vaarala O, Reunanen A, Teramo K, Hämäläinen AM, Paronen J, 
et al. 2010c. Dietary intervention in infancy and later signs of $\beta$-cell autoimmunity. $N$ Engl J Med 363: 19001908.

Kondrashova A, Reunanen A, Romanov A, Karvonen A, Viskari H, Vesikari T, Ilonen J, Knip M, Hyöty H. 2005. A sixfold gradient in the incidence of type 1 diabetes at the eastern border of Finland. Ann Med 37: 67-72.

Kostraba JN, Cruickshanks KJ, Lawler-Heavner J, Jobim LF, Rewers MJ, Gay EC, Chase HP, Klingensmith G, Hamman RF. 1993. Early exposure to cow's milk and solid foods in infancy, genetic predisposition, and risk of IDDM. Diabetes 42: 288-295.

Kukko M, Virtanen SM, Toivonen A, Erkkilä S, Korhonen S, Ilonen J, Simell O, Knip M. 2004. Geographic variation in risk HLA-DQB1 genotypes for type 1 diabetes and signs of $\beta$-cell autoimmunity within a high incidence country. Diabetes Care 27: 676-681.

Kukko M, Kimpimäki T, Korhonen S, Kupila A, Simell S, Veijola R, Simell T, Ilonen J, Simell O, Knip M. 2005. Dynamics of diabetes-associated autoantibodies in young children with HLA-conferred risk of type 1 diabetes recruited from the general population. J Clin Endocrinol Metab 90: 2712-2717.

Lamb MM, Yin X, Barriga K, Hoffman MR, Barón AE, Eisenbarth GS, Rewers M, Norris JM. 2008. Dietary glycemic index, development of islet autoimmunity, and subsequent progression to type 1 diabetes in young children. J Clin Endocrinol Metab 93: 3936-3942.

Lamb MM, Yin X, Zerbe GO, Klingensmith GJ, Dabelea D, Fingerlin TE, Rewers M, Norris JM. 2009. Height growth velocity, islet autoimmunity and type 1 diabetes development: The Diabetes Autoimmunity Study in the Young. Diabetologia 52: 2064-2071.

Lempainen J, Vaarala O, Mäkelä M, Veijola R, Simell O, Knip M, Hermann R, Ilonen J. 2009. Interplay between genetic and dietary factors in type 1 diabetes. J Autoimmun 33: $155-163$.

Lempainen J, Tauriainen S, Vaarala O, Mäkelä M, Honkanen H, Marttila J, Veijola R, Simell O, Hyöty H, Knip M, et al. 2012. Interaction of enterovirus infection and cow's milk based formula nutrition in type 1 diabetes-associated autoimmunity. Diabetes Metab Res Rev 28: 177-185.

Lipponen K, Gombos Z, Kiviniemi M, Siljander H, Hermann R, Veijola R, Simell O, Knip M, Ilonen J. 2010. Effect of HLA class I and class II alleles on progression from autoantibody positivity to overt type 1 diabetes. Diabetes 59: 3253-3256.

Lönnrot M, Korpela K, Knip M, Ilonen J, Simell O, Korhonen S, Savola K, Muona P, Simell T, Koskela P, et al. 2000 Enterovirus infection as a risk factor for B-cell autoimmunity in a prospectively observed birth cohort-The Finnish Diabetes Prediction and Prevention (DIPP) Study. Diabetes 49: 1314-1318.

Mrena S, Savola K, Kulmala P, Åkerblom HK, Knip M, the Childhood Diabetes in Finland Study Group. 2003. Natural course of preclinical Type 1 diabetes in siblings of affected children. Acta Paediatr 92: 1403-1410.

Norris JM, Barriga K, Klingensmith G, Hoffman M, Eisenbarth GS, Erlich HA, Rewers M. 2003. Timing of initial cereal exposure in infancy and risk of islet autoimmunity. JAMA 290: 1713-1720.
Norris JM, Yin X, Lamb MM, Barriga K, Seifert J, Hoffman M, Orton HD, Barón AE, Clare-Salzler M, Chase HP, et al. 2007. Omega-3 polyunsaturated fatty acid intake and islet autoimmunity in children at increased risk for type 1 diabetes. JAMA 298: 1420-1428.

Oikarinen S, Martiskainen M, Tauriainen S, Huhtala H, Ilonen J, Veijola R, Simell O, Knip M, Hyöty H. 2011. Enterovirus RNA in blood is linked to the development of type 1 diabetes. Diabetes 60: 276-279.

Orešič M, Simell S, Sysi-Aho M, Nänto-Salonen K, Seppänen-Laakso T, Parikka V, Mattila I, Keskinen P, Katajamaa M, Yetukuri L, et al. 2008. Dysregulation of lipid and amino acid metabolism precedes autoimmunity in children who later progress to type 1 diabetes. J Exp Med 205: 2975-2984.

Palmer JP, Helquist S, Spinas GA, Mølvig J, Mandrup-Poulsen T, Andersen HU, Nerup J. 1989. Interaction of $\beta$-cell activity and IL- 1 concentration and exposure time in isolated rat islets of Langerhans. Diabetes 38: 1211-1216.

Parikka V, Näntö-Salonen K, Saarinen M, Simell T, Ilonen J, Hyöty H, Veijola R, Knip M, Simell O. 2012. Early seroconversion and rapidly increasing autoantibody concentrations predict prepubertal manifestation of type 1 diabetes in children at genetic risk. Diabetologia doi: 10.1007/s00125-012-2523-3.

Pastore MR, Bazzigaluppi E, Belloni C, Arcovio C, Bonifacio E, Bosi E. 2003. Six months of gluten-free diet do not influence autoantibody titers, but improve insulin secretion in subjects at high risk for type 1 diabetes. J Clin Endocrinol Metab 88: 162-165.

Peng H, Hagopian W. 2006. Environmental factors in the development of Type 1 diabetes. Rev Endocr Metab Disord 7: $149-162$.

Pescovitz MD, Greenbaum CJ, Krause-Steinrauf H, Becker DJ, Gitelman SE, Goland R, Gottlieb PA, Marks JB, McGee PF, Moran AM, et al. 2009. Rituximab, B-lymphocyte depletion, and preservation of $\beta$-cell function. N Engl J Med 361: 2143-2152.

Pflueger M, Seppänen-Laakso T, Suortti T, Hyötyläinen T, Achenbach P, Bonifacio E, Oresic M, Ziegler AG. 2011. Age- and islet autoimmunity-associated differences in amino acid and lipid metabolites in children at risk for type 1 diabetes. Diabetes 60: 2740-2747.

Pociot F, Akolkar B, Concannon P, Erlich HA, Julier C, Morahan G, Nierras CR, Todd JA, Rich S, Nerup J. 2010 Genetics of type 1 diabetes: What's next? Diabetes 59: 1561-1571.

Räsänen M, Kronberg-Kippilä C, Ahonen S, Uusitalo L, Kautiainen S, Erkkola M, Veijola R, Knip M, Kaila M, Virtanen SM. 2006. Intake of vitamin D by Finnish children aged 3 months to 3 years in relation to sociodemographic factors. Eur J Clin Nutr 60: 1317-1322.

Sabbah E, Savola K, Ebeling T, Kulmala P, Vähäsalo P, Salmela P, Knip M. 2000. Genetic, autoimmune, and clinical characteristics of childhood- and adult-onset Type 1 diabetes mellitus. Diabetes Care 23: 1326-1332.

Siljander H, Simell S, Hekkala A, Lähde J, Simell T, Vähäsalo P, Veijola R, Ilonen J, Simell O, Knip M. 2009. Predictive value of diabetes-associated autoantibodies among children with HLA-conferred disease susceptibility recruited from the general population. Diabetes 58: 2835-2842. 
Simonen-Tikka ML, Pflueger M, Klemola P, Savolainen-Kopra C, Smura T, Hummel S, Kaijalainen S, Nuutila K, Natri O, Roivainen M, et al. 2011. Human enterovirus infections in children at increased risk for type 1 diabetes: The Babydiet study. Diabetologia 54: 2995-3002.

Simpson M, Brady H, Yin X, Seifert J, Barriga K, Hoffman M, Bugawan T, Barón AE, Sokol RJ, Eisenbarth G, et al. 2011. No association of vitamin D intake or 25-hydroxyvitamin D levels in childhood with risk of islet autoimmunity and type 1 diabetes: The Diabetes Autoimmunity Study in the Young (DAISY). Diabetologia 54: 27792788.

Stene LC, Joner G, Norwegian Childhood Diabetes Study Group. 2003. Use of cod liver oil during the first year of life is associated with lower risk of childhood-onset type 1 diabetes: A large, population-based, case-control study. Am J Clin Nutr 78: 1128-1134.

Stene LC, Thorsby PM, Berg JP, Rønningen KS, Joner G, Norwegian Childhood Diabetes Study Group. 2008. Peroxisome proliferator-activated receptor- $\gamma 2$ Pro12Ala polymorphism, cod liver oil and risk of type 1 diabetes. Pediatr Diabetes 9: 40-45.

Stene LC, Oikarinen S, Hyöty H, Barriga KJ, Norris JM, Klingensmith G, Hutton JC, Erlich HA, Eisenbarth GS, Rewers M. 2010. Enterovirus infection and progression from islet autoimmunity to type 1 diabetes: The Diabetes and Autoimmunity Study in the Young (DAISY). Diabetes 39: $3174-3180$.

Streng J. 1946. Over de beoordeling van de voedingstoestand in de praktijk (in Dutch, summary in English). Maandschrift $v$ Kindergen 14: 67-78.

Sysi-Aho M, Ermolov A, Tripathi A, Seppänen-Laakso T, Ruohonen ST, Toukola L, Yetukuri L, Härkönen T, Lindfors E, Nikkilä J, et al. 2011. Metabolic regulation in progression to autoimmune diabetes. PLoS Comput Biol 7: e1002257.

Tauriainen S, Oikarinen S, Oikarinen M, Hyöty H. 2011. Enteroviruses in the pathogenesis of type 1 diabetes. Semin Immunopathol 33: 45-55.

The EURODIAB ACE Study Group and The EURODIAB ACE Substudy 2 Study Group. 1998. Familial risk of Type I diabetes in European children. Diabetologia 41: $1151-1156$.

The EURODIAB ACE Study Group. 2000. Variation and trends in incidence of childhood diabetes in Europe. Lancet 355: 873-876.

The EURODIAB Substudy 2 Study Group. 1999. Vitamin D supplement in early childhood and risk of Type I (insulindependent) diabetes mellitus. Diabetologia 42: 51-54.

The EURODIAB Substudy 2 Study Group. 2001. Rapid early growth is associated with increased risk of childhood type 1 diabetes in various European populations. Diabetes Care 25: 1755-1760.

The TRIGR Study Group. 2011. The Trial to Reduce IDDM in the Genetically at Risk (TRIGR ) study: Recruitment, intervention and follow-up. Diabetologia 54: 627-633.

Vaarala O, Knip M, Paronen J, Hämäläinen A-M, Muona P, Väätäinen M, Ilonen J, Simell O, Åkerblom HK. 1999. Cow milk formula feeding induces primary immunization to insulin in infants at genetic risk for type 1 diabetes. Diabetes 48: 1389-1394.
Vaarala O, Atkinson MA, Neu J. 2008. The "perfect storm" for type 1 diabetes: The complex interplay between intestinal microbiota, gut permeability, and mucosal immunity. Diabetes 57: 2555-2562.

Vaarala O, Ilonen J, Ruohtula T, Pesola J, Virtanen SM, Härkönen T, Koski M, Kallioinen H, Tossavainen O, Poussa T, et al. 2012. Removal of bovine insulin from cow's milk formula and early initiation of $\beta$-cell autoimmunity. Arch Pediat Adol Med doi: 10.1001/archpediatrics.2011.1559.

Verge CF, Howard NJ, Irwig L, Simpson JM, Mackerras D, Silink M. 1994. Environmental factors in childhood IDDM: A population-based case-control study. Diabetes Care 17: 1381-1389.

Virtanen SM, Knip M. 2003. Nutritional risk predictors of $\beta$ cell autoimmunity and type 1 diabetes at a young age. $A m$ J Clin Nutr 78: 1053-1067.

Virtanen SM, Räsänen L, Aro A, Lindström J, Sippola H, Lounamaa R, Toivanen L, Tuomilehto J, Akerblom HK. 1991. Infant feeding in Finnish children $<7$ yr of age with newly diagnosed IDDM. Diabetes Care 14: 415-417.

Virtanen SM, Räsänen L, Ylönen K, Aro A, Clayton D, Langholz B, Pitkäniemi J, Savilahti E, Lounamaa R, Tuomilehto J, et al. 1993. Early introduction of dairy products associated with increased risk of IDDM in Finnish children. Diabetes 42: 1786-1790.

Virtanen SM, Hyppönen E, Läärä E, Vähäsalo P, Kulmala P, Savola K, Räsänen L, Knip M, Åkerblom HK, the Childhood Diabetes in Finland Study Group. 1998. Cow's milk consumption, disease associated autoantibodies and Type 1 diabetes mellitus: A follow-up study in siblings of diabetic children. Diabetic Med 15: 730-738.

Virtanen SM, Kenward MG, Erkkola M, Kautiainen S, Kronberg-Kippilä C, Hakulinen T, Ahonen S, Uusitalo L, Veijola R, Simell OG, et al. 2006. Age at introduction of new foods and advanced $\beta$-cell autoimmunity in young children with HLA-conferred susceptibility to type 1 diabetes. Diabetologia 49: 1512-1521.

Virtanen SM, Nevalainen J, Kronberg-Kippilä C, Ahonen S, Tapanainen H, Uusitalo L, Takkinen HM, Niinistö S Ovaskainen M-L, Kenward MG, et al. 2012. Food consumption during childhood and advanced $\beta$-cell autoimmunity in young children with HLA-conferred susceptibility to type 1 diabetes: A nested case-control study. Am J Clin Nutr 95: 471-478.

Viskari H, Kondrashova A, Koskela P, Knip M, Hyöty H. 2006. Circulating vitamin D concentrations in two neighboring populations with markedly different incidence of type 1 diabetes. Diabetes Care 49: 1458-1459.

Wadsworth EJK, Shield JPH, Hunt LP, Baum JD. 1997. A case-control study of environmental factors associated with diabetes in the under 5s. Diabet Med 14: 390-396.

Wen L, Ley RE, Volchkov PY, Stranges PB, Avanesyan L, Stonebraker AC, Hu C, Wong FS, Szot GL, Bluestone JA, et al. 2008. Innate immunity and intestinal microbiota in the development of Type 1 diabetes. Nature 455: $1109-1113$.

Wenzlau JM, Juhl K, Yu L, Moua O, Sarkar SA, Gottlieb P, Rewers M, Eisenbarth GS, Jensen J, Davidson HW, et al. 2007. The cation efflux transporter ZnT8 (Slc30A8) is a major autoantigen in human type 1 diabetes. Proc Natl Acad Sci 104: $17040-17045$. 
Wilkin TJ. 2001. The accelerator hypothesis: Weight gain as the missing link between type 1 and type 2 diabetes. Diabetologia 44: 914-922.

Yeung WC, Rawlinson WD, Craig M. 2011. Enterovirus infection and type 1 diabetes mellitus: Systematic review and meta-analysis of observational molecular studies. BMJ 342: d 35 .

Ziegler A-G, Hummel M, Schenker M, Bonifacio E. 1999. Autoantibody appearance and risk for development of childhood diabetes in offspring of parents with type 1 diabetes: The 2-year analysis of the German BABYDIAB Study. Diabetes 48: 460-468.

Ziegler A-G, Schmid S, Huber D, Hummel M, Bonifacio E. 2003. Early infant feeding and risk of developing Type 1 diabetes-associated autoantibodies. JAMA 290: 17211728.

Zipitis CS, Akobeng AK. 2008. Vitamin D supplementation in early childhood and risk of type 1 diabetes: A systematic review and meta-analysis. Arch Dis Childr 93: 512517. 


\section{$\&_{\mathrm{CSH}}^{\infty} \&$ Cold Spring Harbor

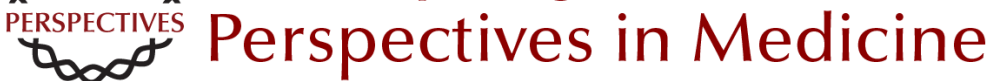

\section{Environmental Triggers of Type 1 Diabetes}

Mikael Knip and Olli Simell

Cold Spring Harb Perspect Med 2012; doi: 10.1101/cshperspect.a007690 originally published online May 23, 2012

\section{Subject Collection Type I Diabetes}

The Pathogenesis and Natural History of Type 1 Diabetes

Mark A. Atkinson

Do MHCII-Presented Neoantigens Drive Type 1

Diabetes and Other Autoimmune Diseases?

Philippa Marrack and John W. Kappler

Clinical Immunologic Interventions for the

Treatment of Type 1 Diabetes

Lucienne Chatenoud, Katharina Warncke and

Anette-G. Ziegler

Update on Islet Transplantation

Michael McCall and A.M. James Shapiro

Immunologic and Metabolic Biomarkers of $\beta$-Cell

Destruction in the Diagnosis of Type 1 Diabetes Jasmin Lebastchi and Kevan C. Herold

Advancing Animal Models of Human Type 1

Diabetes by Engraftment of Functional Human

Tissues in Immunodeficient Mice

Michael A. Brehm, Alvin C. Powers, Leonard D.

Shultz, et al.

Breakdown in Peripheral Tolerance in Type 1

Diabetes in Mice and Humans

Lukas T. Jeker, Hélène Bour-Jordan and Jeffrey $A$. Bluestone

Antigen-Specific Therapeutic Approaches in Type 1 Diabetes

Xavier Clemente-Casares, Sue Tsai, Carol Huang, et al.
Humoral Autoimmunity in Type 1 Diabetes:

Prediction, Significance, and Detection of Distinct

Disease Subtypes

Massimo Pietropaolo, Roberto Towns and George

S. Eisenbarth

Endoplasmic Reticulum Stress, Pancreatic $\beta$-Cell

Degeneration, and Diabetes

Feroz R. Papa

Islet Autoantigens: Structure, Function,

Localization, and Regulation

Peter Arvan, Massimo Pietropaolo, David Ostrov, et al.

Environmental Triggers of Type 1 Diabetes Mikael Knip and Olli Simell

Generating $\beta$ Cells from Stem Cells--The Story So

Far Matthias Hebrok

Antigen Targets of Type 1 Diabetes Autoimmunity Bart O. Roep and Mark Peakman

Connecting Type 1 and Type 2 Diabetes through Innate Immunity Justin I. Odegaard and Ajay Chawla

The Hygiene Hypothesis: An Explanation for the Increased Frequency of Insulin-Dependent Diabetes Jean-François Bach and Lucienne Chatenoud

For additional articles in this collection, see http://perspectivesinmedicine.cshlp.org/cgi/collection/ 